\title{
Proline-Rich AKT1 Substrate 1
}

National Cancer Institute

\section{Source}

National Cancer Institute. Proline-Rich AKT1 Substrate 1. NCI Thesaurus. Code C101616.

Proline-rich AKT 1 substrate 1 ( $256 \mathrm{aa}, \sim 27 \mathrm{kDa}$ ) is encoded by the human AKT $1 \mathrm{~S} 1$ gene.

This protein plays a role in $\mathrm{mTOR}$-dependent signaling. 